\title{
Global Retailers and Competitive Customer Value
}

\author{
Sabina Riboldazzi*
}

\begin{abstract}
Global competition involves large retailers in a continuous development of their activity in relation to market stimula. In this regard efficient management of commercial functions, innovation of offer attributes and dynamic management of retailing mix allow large retailers to reformulate their offer creating competitive customer value.
\end{abstract}

Keywords: Global Retailers; Market-Driven Management; Competitive Customer Value; Global Competition

\section{Italian Retailers and Global Markets}

The distribution system has gone through a process of intense structural transformation over the last few years, and this has led to a change in the role of distributors who have moved from a position of passive intermediation to an active managerial one, participating constructively in globalisation processes.

The entity and consistency of the transformations which have affected the distribution sector have become evident in different ways and timescales in the various geographical contexts, and these differences are reflected in the present competitive scene.

In the United States, the development of modern distribution occurred in the period between the two world wars; in Europe, a progressive move from traditional forms of sale to modern distribution spread after the second world war; in Italy, modernisation of the distribution system developed at great speed only in the nineteen eighties, determining a progressive reduction in traditional forms of distribution in the space of just twenty years ${ }^{1}$.

Notwithstanding this driving development, the delay in the Italian distribution system's evolutionary process has not allowed national firms to aspire to a role of any importance on either the European market $^{2}$ or the global one.

* Research Fellow of Management, University of Milan-Bicocca (sabina.riboldazzi@ unimib.it)

Riboldazzi Sabina, Global Retailers and Competitive Customer Value, Symphonya. Emerging Issues in Management (symphonya.unimib.it), n. 2, 2005, pp. 77-87 
Table 1: Large Scale Retail Trade Firms in Europe (2005)

\begin{tabular}{|c|c|c|c|c|}
\hline RETAILER & COUNTRY & $\begin{array}{c}\text { SALES } \\
\text { (MILLIONS } \\
\text { OF EURO) }\end{array}$ & $\begin{array}{c}\% \\
\text { GROCERY }\end{array}$ & $\begin{array}{c}\text { \% SALES } \\
\text { ENTIRE } \\
\text { MARKET }\end{array}$ \\
\hline Carrefour & $\mathrm{F}$ & 77.094 & 74,6 & 57,6 \\
\hline Metro Group & $\mathrm{D}$ & 64.221 & 46,5 & 49,7 \\
\hline Tesco & UK & 55.095 & 72,4 & 86,7 \\
\hline Rewe & $\mathrm{D}$ & 45.478 & 76,4 & 69,4 \\
\hline Schwarz Group & $\mathrm{D}$ & 40.381 & 82,5 & 56,2 \\
\hline Edeka & $\mathrm{D}$ & 40.322 & 85,5 & 93,4 \\
\hline Auchan & $\mathrm{F}$ & 38.083 & 62,0 & 55,8 \\
\hline Aldi & $\mathrm{D}$ & 32.275 & 82,6 & 67,2 \\
\hline Leclerc & $\mathrm{F}$ & 31.810 & 63,0 & 94,4 \\
\hline Casino & $\mathrm{F}$ & 30.375 & 74,7 & 58,1 \\
\hline Itm & $\mathrm{F}$ & 29.410 & 65,6 & 90,4 \\
\hline Ahold & NL & 26.489 & 78,0 & 41,4 \\
\hline Asda (Wal-Mart) & UK & 26.226 & 68,0 & 100,0 \\
\hline Sainsbury & UK & 25.329 & 75,7 & 100,0 \\
\hline Morrison & $\mathrm{UK}$ & 19.402 & 78,0 & 100,0 \\
\hline Tengelmann & $\mathrm{D}$ & 18.924 & 57,5 & 74,7 \\
\hline El Corte Ingles & $E$ & 18.753 & 23,8 & 98,3 \\
\hline System U & $\mathrm{F}$ & 15.050 & 85,3 & 100,0 \\
\hline Migros & $\mathrm{CH}$ & 14.305 & 59,6 & 98,9 \\
\hline Co-operative Group & UK & 13.989 & 28,0 & 100,0 \\
\hline Coop Norden & $\mathrm{S}$ & 13.693 & 81,3 & 33,6 \\
\hline Coop Swisse & $\mathrm{CH}$ & 12.044 & 68,0 & 100,0 \\
\hline Mark \& Spencer & UK & 12.011 & 45,4 & 100,0 \\
\hline Coop Italia & $\mathrm{I}$ & 11.473 & 84,9 & 99,6 \\
\hline Lekkerland & $\mathrm{D}$ & 11.035 & 95,7 & 60,4 \\
\hline Kesko & FL & 10.852 & 40,9 & 88,0 \\
\hline Louis Delhaize & $\mathrm{B}$ & 10.675 & 67,1 & 69,8 \\
\hline Mercadona & $\mathrm{E}$ & 10.338 & 97,0 & 100,0 \\
\hline Baugur & IS & 10.268 & 62,6 & 4,1 \\
\hline Sok & FL & 8.802 & 53,1 & 98,9 \\
\hline
\end{tabular}

Source: Author's Own Elaborations Using Planet Retail Data

Table 1 shows how numerous European firms have pursued development strategies by moving outside the boundaries of their nation of origin and, in some cases, becoming important players in global competition, as the following classification demonstrates ${ }^{3}$ : Wal-Mart (USA- 273.000 million Euro), Carrefour (F-94.000 million Euro), Metro Group (D-67.000 million Euro), Tesco (UK-62.000 million Euro), Ahold (NL-61.000 million Euro), Kroger (USA-50.000 million Euro), Sears (USA-49.000 million Euro), Seven \& I. (J- 48.000 million Euro), Rewe (D-46.000 million Euro), Costco (USA-45.000 million Euro).

Therefore, in the European context, following modernisation and internationalisation phenomena ${ }^{4}$, the distribution sector is composed of a limited number of large companies of such size as to cross national borders, allowing them to become important organisations in global competition; in Italy, on the other hand, there is still a high amount of parcelling up of the distribution market, which is emphasised by a reduced concentration of so-called modern distribution firms. 
Figure 1: Market Concentration: Market Quota of The Top 5 Distributors (Year 2005)

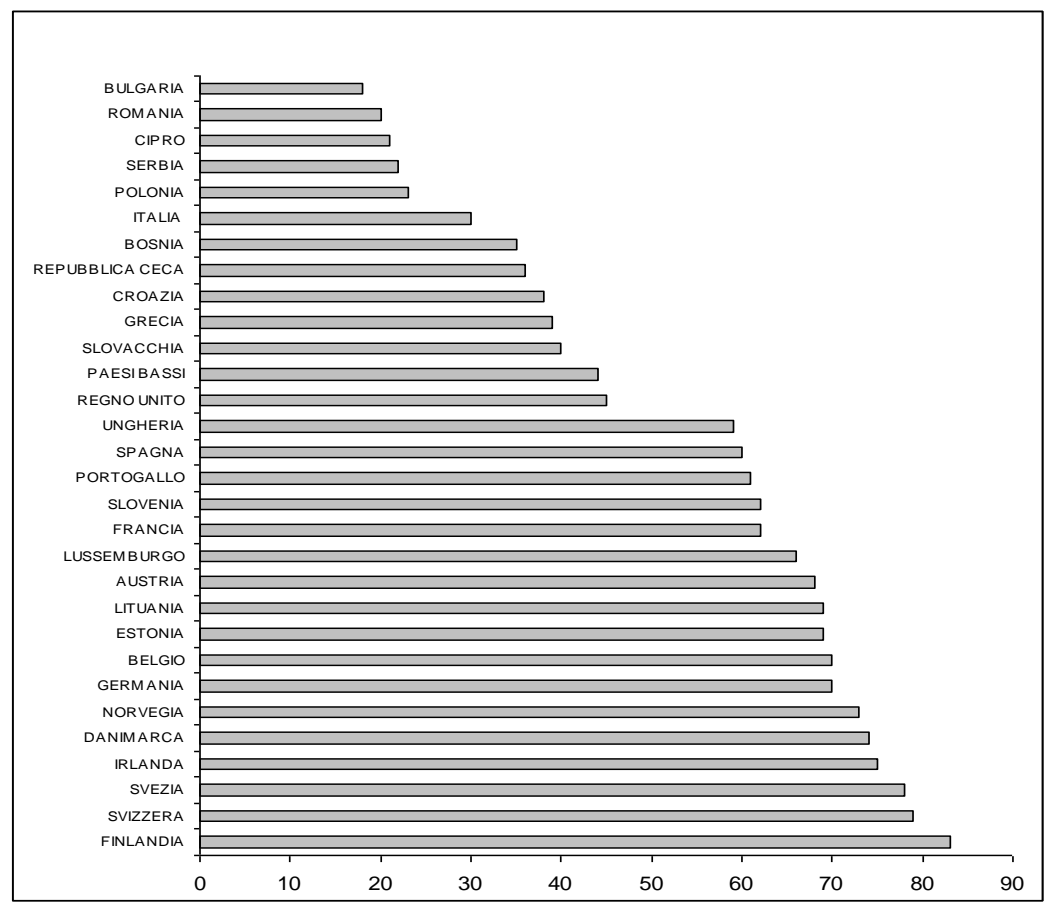

Source: DPC-COOP ITALIA Elaborations Using Planet Retail Data

Hence, the present distribution system is made up of a few large companies which, fighting in conditions of high competition and consumption saturation, are constantly engaged in a re-formulation of their supplies in order to find new sources of value creation.

\section{Large Scale Retail Trade Businesses and Competitive Customer Value}

Open competition, higher production than the absorption capacity of demand achieved through attainment of economies of cost, ever more sophisticated products but rapidly rendered obsolete by ease of imitation ${ }^{5}$ are factors which characterise markets in which large retailers operate; these factors induce the companies to continually search for innovation and efficiency, stimulated by a corporate management with market knowledge priorities, aimed at the creation of competitive customer value.

A simplified outline of customer value expresses it as a perception of the ratio between the benefits and costs associated with a given supply. The indicated relationship is not sufficient to guarantee a value which makes the exchange desirable or satisfying ${ }^{6}$ for demand; therefore the value must be higher compared to the one obtainable from competitors' supplies and consequently the firm must be involved in a continual process of anticipation of its competitors, identifying market changes which could translate into value determinants; so it is not sufficient for anyone to limit themselves to considering the value perceived by current customers with respect to a corporate supply; this knowledge has to also be 
extended to a comparison with competitors' supplies, both with reference to present customers and with reference to potential customers, in order to assess value solidity compared to that of competitors and its attractiveness to a wider market.

Therefore in global markets, which are characterised by oversupply, the thing that can determine the success of corporate strategy is a capacity for learning new and original value boundaries ${ }^{7}$ from the market, in a context of behaviour driven towards continual change.

The close relationship between distributors and consumers means that a great deal of data returned from the market is processed in the distributors' own information systems ${ }^{8}$; as the latter have accurate and sophisticated information concerning demand and operate in situations of high intensity competition, they are committed to continual renewal of their own supplies so as to produce competitive customer value.

In order to understand the value determinants for both current and potential customers of distribution firms, it is best to define the concept of commercial supply and identify the main roles performed by distribution firms in a situation of high global competition.

The general role of distribution firms consists in reducing the imbalances which exist between places, times and methods of manufacture, on the one hand, and consumption, on the other ${ }^{9}$, through the creation of utility of place, time and possession $^{10}$. This general role can be split into a series of fundamental roles which must be performed to guarantee effective and efficient meeting between demand and supply ${ }^{11}$. One possible classification of the fundamental roles of distribution firms is the following: logistics ${ }^{12}$, assortment ${ }^{13}$, contact $^{14}$, information ${ }^{15}$, communication $^{16}$, economic-financial ${ }^{17}$ and production roles ${ }^{18}$.

Numerous roles attributed to distribution firms can be traced back to the attributes that some authors quote in the definition of a commercial product.

A commercial supply can be defined as 'a set of fundamental factors combined in different proportions which we might call attributes; a specific consumer utility corresponds to each of these attributes because the availability of a greater quantity of any attribute reduces its purchase cost ${ }^{19}$. Therefore, it is possible to define a commercial supply as a basket of attributes which may be broken down into a central nucleus and a series of peripheral services. 'The central nucleus is defined in relation to the availability of an assortment of goods offered to the potential purchaser; the peripheral sphere, on the other hand, includes a whole series of accessory services (pre-sales services, access, services during sales, post-sales services) which enrich the proposal, marking time in relation to the various purchase moments, ${ }^{20}$.

Therefore a distribution firm will manage to create competitive customer value through continual innovation of the components constituting the commercial product and through its capacity to exercise the functions that it is in charge of in an efficient way.

Innovation must involve the entire distribution value chain which is split into content (prices and product offered), context (which refers predominantly to the point of sale) and infrastructure (which makes reference to the production process of the service and the degree of involvement, both of the consumer and the supplier, in the process itself) $^{21}$; therefore conceptual innovations, which refer to front-office, must 
be joined by flow innovations concerning vertical channel relationships and organisational innovations, to improve management of the network ${ }^{22}$.

Consequently innovation also drives dynamic management of retailing mix levers, which are managed and coordinated as a reflection of the continual stimulations exercised by the market.

Figure 2: Value Drivers of Large Scale Retail Trade Businesses

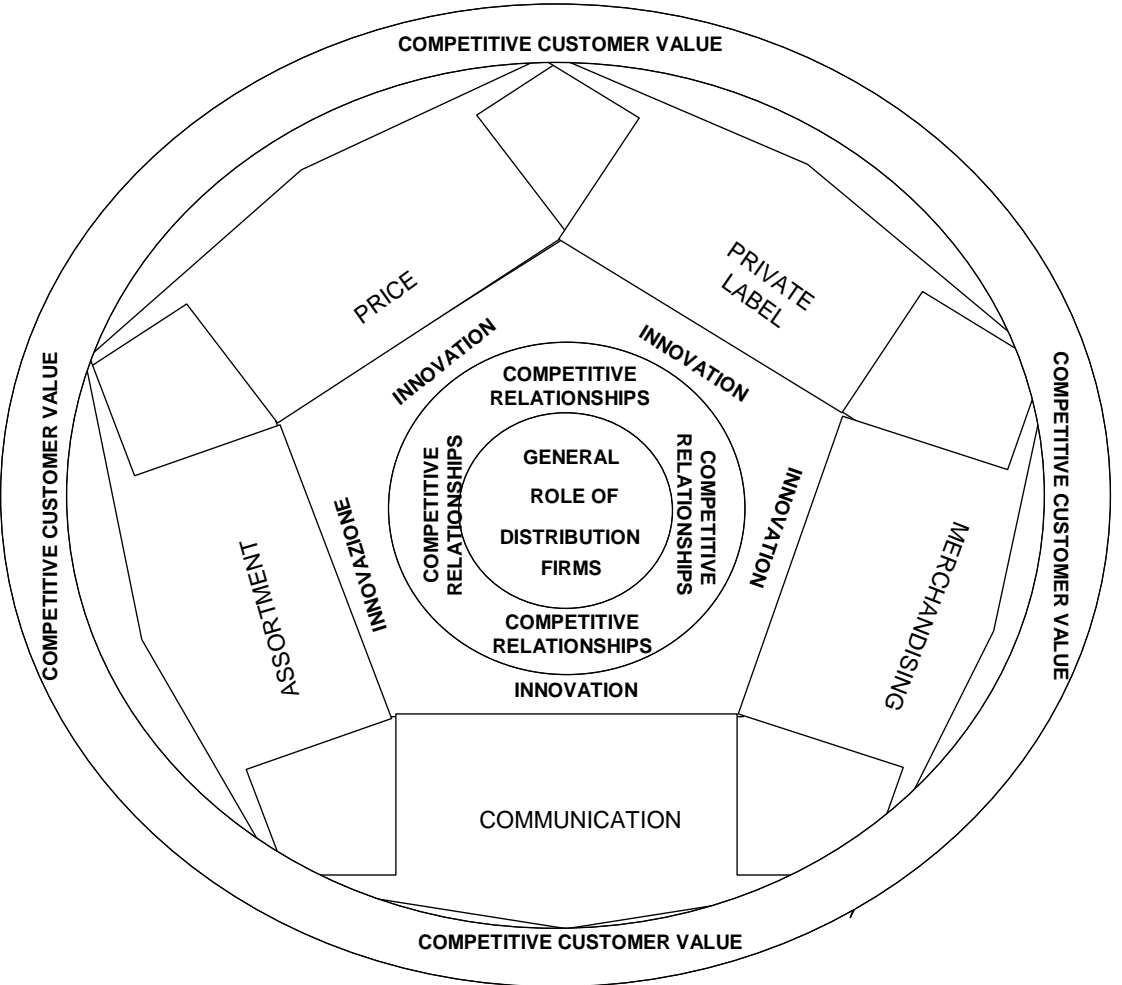

The capacity to adapt decisions about assortment ${ }^{23}$, prices and merchandising ${ }^{24}$ to market changes is conditioned by the competitive relationships established by the firm and therefore, the capacity to generate competitive customer value depends on intensity of sharing of defined resources in a networking system characterised by collaboration between internal, external and co-makership structures ${ }^{25}$. Resources sharing is also recognisable in the collaboration between industry and distribution with reference to private label ${ }^{26}$ strategies; by allowing distributors to assume a system of brand responsibility which is very similar to that of manufacturers. This strengthens the retailers' capacity to produce competitive value.

Therefore the main objective of communication ${ }^{27}$, besides supporting commercial promotions, which normally produce short term sales which are difficult to maintain over time ${ }^{28}$, is to convey a promise of value and store brand values, which are understood as a specific relationship established with a given market for the affirmation of a particular supply ${ }^{29}$, in order to induce the establishment of strong relationships which form the basis of competitive customer value. Therefore, the creation of competitive value induces recognition of the important role assumed by new data processing technologies; these support management of the corporate information system ${ }^{30}$ and therefore allow the assessment and distribution, in good time, of pertinent and valid information which renders corporate decisions timely in 
respect to the stimuli exercised by the market. Moreover, through sharing of information between companies ${ }^{31}$, the same technologies make the system of corporate relationships more effective and efficient, impacting, in particular, the horizontal relationships (entertained with competitors) and the vertical relationships (entertained with companies who carry out upstream and downstream phases in the supply chain). EDI, bar codes, POS Scanners, fidelity cards ${ }^{32}$, are only a few examples ${ }^{33}$ of applications which have made logistics processes, buying processes, information exchange between firms and the interface with the end customer more effective and efficient and which, therefore, have permitted significant innovation in the distribution sector. More recent applications ${ }^{34}$ can be linked to the use of joint marketplaces for the realisation of inverse electronic auctions, revolving cards and the application of RFID solutions. Inverse electronic auctions are based on an exchange process, through a digital platform, where the distribution firm demands a determinate supply and several suppliers compete to win the order, negotiating in real time according to rules fixed by the distributor itself. Revolving cards allow the granting of credit, in the form of payment deferments, for consumers who wish to make purchases of durable and non durable goods. The application of RFID ${ }^{35}$ solutions through the installation of tags which emit electronic signals on individual products, allows the monitoring of the products along the entire supply chain permitting the improvement of integration processes and information sharing between channel players.

Resources sharing, innovation and efficiency are, therefore, important objectives which must be pursued by large retailers for the creation of competitive customer value.

\section{Bibliography}

Alderson Wroe, Marketing Behaviour and Executive Action. A Functionalist Approach to Marketing Theory, Homewood, Irvin, 1957.

Anderson J.C., Fornell C., Lehmann D.R., Customer Satisfaction, Market Share and Profitability: Findings From Sweden, Journal of Marketing, July, 1994. http://dx.doi.org/10.2307/1252310

Anderson James C., Jain Dipak C., Chintagunta Pradeep K., Customer Value Assessment in Business Markets: A State of Practice Study, Journal of Business to Business Marketing, n.1, 1993.

Artle Roland, Berglund Sture, A Note on Manufacturers' Choice of Distribution Channel, Management Science, July, 1959.

http://dx.doi.org/10.1287/mnsc.5.4.460

Baccarani Claudio, (ed.) Imprese commerciali e sistema distributivo, una visione economicomanageriale, Giappichelli, Turin, 1997.

Balderston Frederick E., Communication Network in Intermediate Markets, Management Science, January, 1958.

http://dx.doi.org/10.1287/mnsc.4.2.154

Best Roger J., Market-Based Management Strategies for Growing Customer Value and Profitability, Pearson Prentice Hall, New Jersey, 2005.

Brondoni Silvio M., Brand Policy and Brand Equity, Symphonya. Emerging Issues in Management (symphonya.unimib.it), n. 1, 2000-2001. 
http://dx.doi.org/10.4468/2001.1.02brondoni

Brondoni Silvio M., Comunicazione integrata d'impresa e 'nuove sfide competitive', AA.VV., Progettare e gestire l'impresa innovativa, ETAS, Milan, 1992.

Brondoni Silvio M., Comunicazione, risorse invisibili e strategia competitiva d'impresa, in S.M. Brondoni S.M., La comunicazione d'impresa, Sinergie, Maggio-Dicembre, 1997.

Brondoni Silvio M., La nuova visione delle economie di scala, MARK UP, Dicembre, 2004.

Brondoni Silvio M., Ouverture de 'Market-Space Management', Symphonya, Emerging Issues in Management (symphonya.unimib.it), n. 1., 2002. http://dx.doi.org/10.4468/2002.1.010uverture

Brondoni Silvio M., Patrimonio di marca e risorse immateriali d'impresa, Giappichelli, Turin, 2004.

Buzzel Robert, Gale Bradley, The Pims Principles: Linking Strategy to Performance, The Free Press, New York, 1987.

Cafferata Roberto, Sistemi ambiente e innovazione. Come s'integrano la continuità e il mutamento nell'impresa, Giappichelli, Turin, 1995.

Castaldo Sandro, Retailing \& Innovazione, EGEA, Milan, 2001.

Colla Enrico, La grande distribuzione in Europa. Evoluzione delle formule distributive, strategie $e$ strutture aziendali, rapporti con l'industria, ETAS, Milan, 1995.

Corniani Margherita, Sistema informativo aziendale e dinamiche competitive, Giappichelli, Turin, 2000.

Cristini Guido, Le strategie di marca del distributore, differenziazione dell'offerta e vantaggio competitivo, EGEA, Milan, 1992.

Day George S., Market Driven Strategy, Processes for Creating Value, The Free Press, New York, 1999.

Dayan Armand, Sbrana Roberto, La distribuzione commerciale, Giappichelli, Turin, 1994.

de Woot Philippe, The Challenges of Economic Globalisation: Business, Competition and Society, Symphonya. Emerging Issues in Management (symphonya.unimib.it), n. 2, 2002. http://dx.doi.org/10.4468/2002.2.03dewoot

Deshpande Rohit, Farley John U., Webster Frederick E., Corporate Culture, Customer Orientation and Innovativeness in Japanese Firms: a Quadraq Analysis, Journal of Marketing, January, 1993. http://dx.doi.org/10.2307/1252055

El-Ansary Adel I., Stern Louis W., Power Measurement in the Distribution Channel, Journal of Marketing Research, n. 21, 1972. http://dx.doi.org/10.2307/3149605

Fabrizi C., I canali di distribuzione nella teoria e nella pratica, AA.VV., Saggi di economia aziendale e sociale in memoria di Gino Zappa, Giuffrè, Milan, 1961.

Filser Marc, I canali della distribuzione: organizzazione, analisi delle formule di vendita, metodi di gestione, ETAS, Milan, 1992.

Fornari Daniele, Rivoluzione commerciale \& Trade Marketing, EGEA, Milan, 1999.

Gennari Francesca, Category Management e vantaggio competitivo, Giappichelli, Turin, 2004.

Gnecchi Flavio, La private label nell'economia dell'impresa, Giappichelli, Turin, 2002.

Golinelli Gaetano M., Gatti Mauro, The Firm as a Viable System, Symphonya. Emerging Issues in Management (symphonya.unimib.it), n. 2, 2000-2001.

http://dx.doi.org/10.4468/2001.2.04golinelli.gatti

Holton Richard, The Distinction between Convenience Goods, Shopping Goods and Speciality Goods, Journal of Marketing, vol. 23, July, 1958. 
http://dx.doi.org/10.2307/1248017

Inmon William H., Building in Data Warehouse, Wiley, New York, 1996.

Jaworski Bernard J., Kohli Ajay K., Market Orientation: Antecedents and Consequences, Journal of Marketing, July, 1993.

http://dx.doi.org/10.2307/1251854

Kotler Philip, Armstrong Gary, Saunders John, Wong Veronica, Principi di marketing, ISEDI, Milan 2001.

Lambin Jean-Jacques, Brondoni Silvio M., Ouverture de 'Market-Driven Management', Symphonya. Emerging Issues in Management (symphonya.unimib.it), n. 2, 2000-2001.

http://dx.doi.org/10.4468/2001.2.01ouverture

Lambin Jean-Jacques, Strategic Marketing Revisited After September 11, Symphonya. Emerging Issues in Management (symphonya.unimib.it), n. 1, 2002. http://dx.doi.org/10.4468/2002.1.02lambin

Lambin Jean-Jacques, Marketing strategico e operativo. Market-Driven Management, McGraw-Hill, Milan, 2004.

Lugli Giampiero, Economia e politiche di marketing delle imprese commerciali, UTET, Turin, 1993.

Lugli Giampiero, Pellegrini Luca, Marketing Distributivo, La creazione di valore nella distribuzione despecializzata, UTET, Turin, 2005.

Lugli Giampiero, Ziliani Cristina, Micromarketing, Creare valore con le informazioni di cliente, UTET, Turin, 2004.

Mallen Bruce, (ed.), The Marketing Channel. A Conceptual Viewpoint, John Wiley and Sons Inc., New York, 1967.

Marino Alberto, Competizione distributiva e politica di mercato dell'impresa, Giuffrè, Milan, 1988.

Musso Fabio, Relazioni di canale e strategie di acquisto delle imprese commerciali, potere e stabilità nella grande distribuzione britannica, Lint, Trieste, 1999.

Narver John C., Slater Stanley F., The Effect of Market Orientation on Business Profitability, Journal of Marketing, October, 1990. http://dx.doi.org/10.2307/1251757

Normann Richard, La gestione strategica dei servizi, ETAS, Milan, 1985.

Pellegrini Luca, Economia della distribuzione, EGEA, Milan, 1990.

Porter Michael E., Il vantaggio competitivo, Edizioni La Comunità, Milan, 1987.

Reichhelf Frederick F., Schefter Phil, E-Loyalty. Your Secret Weapon on The Web, Harvard Business Review, July-August, 2000.

Rucci Anthony J., Kirn Steven P., Quirn Richard T., The Employee-Customer-Profit Chain at Sears, Harvard Business Review, January-February, 1998.

Sicca Lucio, prefazione al libro di A.N. Cantone, Creazione di valore attraverso le relazioni con $i$ clienti, Edizioni Scientifiche Italiane, Naples, 1996.

Spranzi Aldo, Economia del commercio e politica commerciale, Franco Angeli, Milan, 1985.

Spranzi Aldo, L'efficienza della distribuzione commerciale, ETAS, Milan, 1969.

Webster Frederick J., Market-Driven Management. How to Define, Develop and Deliver Customer Value, John Wiley \& Sons, New York, 2002.

Zaninotto Enrico, La gestione collaborativa della funzione distributiva, EGEA, Milan, 1990.

Zusman Pinhas, Etgar Michael, Marketing Channel as an Equilibrium Set of Contracts, Management Science, March, 1981. 


\section{Notes}

${ }^{1}$ The market share for traditional commerce gradually diminished from 1997 to 2006, dropping from $27 \%$ to just $16 \%$. Source: AcNielsen.

${ }^{2}$ It can be noted in Table 1 that there is only one Italian retailer, Coop Italia which occupies twenty fourth position, in the classification of the top thirty European retailers.

${ }^{3}$ Revenues in millions of Euros of the top ten distributors in the world. Source: M+M Planet Retail - 2005 .

${ }^{4}$ According to AcNielsen-GNLC the market share of foreign distribution in Italy rose from $2.7 \%$ in 1991 to $32.1 \%$ in 2005 .

${ }^{5}$ See. S.M. Brondoni, Comunicazione, risorse invisibili e strategia competitiva d'impresa, in S.M. Brondoni, La comunicazione d'impresa, in Sinergie, Maggio-Dicembre, 1997.

${ }^{6}$ Customer value can be linked to customer satisfaction; customer satisfaction is created when the result of the difference between perceived value and expected value from the corporate supply system is positive.

${ }^{7}$ See. G.S. Day, Market Driven Strategy, Processes for Creating Value, The Free Press, New York, 1999.

${ }^{8}$ See. M. Corniani, Sistema informativo aziendale e dinamiche competitive, Giappichelli, Turin, 2000 .

${ }^{9}$ See. J.J. Lambin, Marketing strategico e operativo. Market-Driven Management, McGraw-Hill, Milan, 2004.

${ }^{10}$ Physical transfer of a product from one region (of production) to another (of consumption) can add an evident benefit of place to that product; its storage in the warehouse from time of production to time of sale increases the product's value as a result of a time benefit. Lastly, the benefit of possession is related to the fact that a product,purchased by a consumer to satisfy a need acquires a greater benefit than it had for the seller. On the matter of benefit of place see: L. Pellegrini, Economia della distribuzione, EGEA, Milan, 1990; the Author upholds that a retail company has its very reason for being in the necessity for spatial connection between production and consumption.

${ }^{11}$ See. B. Mallen, (a cura di), The Marketing Channel. A Conceptual Viewpoint, John Wiley and Sons Inc., New York, 1967. The Author can be numbered amongst the first scholars who found in specialisation justification for the presence of intermediaries; distribution firms permit economies of specialisation which improve channel efficiency.

${ }^{12}$ Amongst the activities belonging to this function are included: supplying, conservation, qualiquantitative adaptation of lots, transport.

13 See. W. Alderson, Marketing Behaviour and executive action. A functionalist approach to marketing theory, Homewood, Irvin, 1957. The Author is one of the first scholars to have identified matching between demand and supply as a main function of intermediaries; by uniting the supplies of several industrial firms, a distribution firm reduces the technological gap existing between supply and consumption.

14 See. R. Artle, S. Berglund, A note on manufacturers' choice of distribution channel, Management Science, July, 1959. The Authors have demonstrated the contribution, in terms of efficiency, provided by the position which intermediaries take up in the channel; they facilitate exchange and reduce the number of transactions; in fact, with intermediation there is a reduction in the number of contacts which become $\alpha+\beta$ and no longer $\alpha \times \beta$.

${ }^{15}$ See. F.E. Balderston, Communication network in intermediate markets, Management Science, January, 1958. The Author can be numbered amongst the first scholars who justified the presence of 
intermediaries by entrusting them with the role of managers of information flows; the channel is considered a communication network and intermediaries are the principal players for the purpose of retrieval of important information from the market.

${ }^{16}$ Communication activities refer to communication flows issued by a firm towards the various audiences to which it addresses itself.

${ }^{17}$ Amongst the activities belonging to this role: definition of prices and forms of financing with reference to production and consumption.

18 Reference is being made to cases in which distributors have their own factories for the production of private label goods.

${ }^{19}$ See. L. Pellegrini, La domanda dei servizi commerciali, in G. Lugli, L. Pellegrini, Marketing Distributivo, La creazione di valore nella distribuzione despecializzata, UTET, Turin, 2005. The Author identifies the attributes of trade service by dividing them into logistics (neighbouring, warehousing, opening hours) informational (preliminary selection, assortment, direct information) and others (post-sales, speed of service, comfort).

${ }^{20}$ Pre-sales services include all activities aimed at: supplying sufficient information and choosing the point of sales, coordinating the process of orders and bookings acceptance, developing projects related to the use of goods purchased. Services relating to access can be classified in: point of sale hours, parking, home delivery as an extension of the point of sales. Services during sales can be traced to: atmosphere, merchandising, availability of equipment for the disabled and children, presence of support services such as bars, telephones, etc., staff courtesy and professionalism, information for the purpose of assessing the quality-price ratio of products, reordering, merchandising, diversification of methods of payment, checking queue length at checkouts, clarity of receipts, product packaging, granting of credit to customers. Post-sales services may possibly number the following: product guarantees, setting up of a structure for interaction with customers in order to spot ongoing changes in the needs to be satisfied. See. C. Baccarani, cit. 1997.

${ }^{21}$ See. G. Lugli, Il 'prodotto’ delle imprese commerciali, in G. Lugli, L. Pellegrini, cit., 2005.

${ }^{22}$ See. S. Castaldo, Retailing \& Innovazione, EGEA, Milan, 2001.

${ }^{23}$ Decisions concerning assortment refer to choices relating to the width, depth and variety of the assortment itself and to the combination between leading brands, followers, national brands, local brands and private labels.

${ }^{24}$ Decisions concerning merchandising refer to the choices relating to the layout of equipment, product layout and the allocation of display space for the purpose of creating readable and informative sales spaces which, besides optimising the use of the sales capacity, facilitate the customer's purchase process.

${ }^{25}$ See. S.M. Brondoni, La nuova visione delle economie di scala, in Mark Up, Dicembre 2004.

${ }^{26}$ Private labels are, through the exclusiveness of sales, the main element of differentiation of distribution firms. They allow the development of solid relationships with consumers which generate greater value for the firm and therefore for the consumers themselves.

27 The following is a brief classification of the communication tools used by distribution firms: direct mailing consists in sending out a direct advertising communication; telemarketing allows marketing activities to be carried out over the telephone with the aim of both retention and acquisition; web sites consist in the purchase of a space on the web in order to make known own supplies (display window) and in order to establish a relationship with the consumer; e-mailing is the sending out of a communication over the internet; SMS consists in sending personalised messages by cell phone; electronic kiosks which are, in fact, virtual store; self-scanning consists in using portable terminals which allow customers to receive important information and make out their own receipt as products are placed in the shopping trolley, in such a way that, once they reach the check out, it is sufficient to download the file from the portable terminal in order to pay; POS Scanners allow personalised receipts which indicate, for example, the owner's name, number of points collected, reserved offers, etc. or the printing of discount vouchers which permit the production of personalised 
coupons that the customer can use in subsequent shopping expeditions. See. G. Lugli, C. Ziliani, Micromarketing, Creare valore con le informazioni di cliente, UTET, Turin, 2004.

${ }^{28}$ See. P. Kotler, G. Armstrong, J. Saunders, V. Wong, Principi di marketing, ISEDI, Milan, 2001.

29 See. S.M. Brondoni, Brand Policy and Brand Equity, in Symphonya. Emerging Issues in Management (symphonya.unimib.it), n. 1, 2000-2001; S.M. Brondoni, Patrimonio di marca e risorse immateriali d'impresa, G. Giappichelli, Turin, 2004.

${ }^{30}$ See. M. Corniani, 2000, cit.

${ }^{31}$ Reference is made to inter-company information systems or to those components of information systems that are shared by several firms.

${ }^{32}$ EDI allows the automatic transfer of structured information between the information systems of producers, distributors and third parties involved in the exchange; therefore, thanks to the optimisation of timings, reduction of risks of error, reduction of stock, it allows higher levels of efficiency and effectiveness to be achieved in the service delivery process. Bar codes and Pos Scanners allow more efficacious management of the various logistics functions, from purchases right through to sales; moreover, in combination with fidelity cards they allow an understanding of purchase behaviour at the level of individual customers for personalisation of marketing initiatives and the creation of a data warehouse which allows the transformation of data into useable information to support corporate activities.

${ }^{33}$ For the sake of completeness the following are also cited: Fast Perfect Order-EDI applications (Fast Perfect Order is an integrated solution between producer, distributor and third parties which aims to optimise and standardise goods and information exchange flows and processes. EDI represents the technological infrastructure of communication which is the fundamental qualifying factor for the correct and effective functioning of the process), OSA (Optimal Shelf Availability allows improvement of availability on the shelf of products through the measuring of Out-of-Stock products, identification of the main causes, and fine tuning of solutions), CRP (Continuous Replenishment Program - is a process which, against information received from the distributor, entrusts the manufacturer with the responsibility of order issuing and management of the level of stock held at CEDI), CPRF (Collaborative Planning, Forecasting \& Replenishment - extends the ambit of collaboration between producers and distributors to the order planning and forecasting stages, moving the perspective to the medium-long term period), and CRM applications (Customer Relationship Management - a collaborative strategy which, through joint work on knowledge of customer behaviour, demand segmentation, differentiation and personalisation of supplies, develops a lasting relationship with the consumer which targets his/her satisfaction and the generation of value for industry and distribution).

${ }^{34}$ Used by some Italian distributors, but only over the last few years.

35 A tag is applied to every product containing information about the product itself; by going through the automatic devices placed at the exit to the production warehouse, the entrance and exit to the distribution centre and the entrance and exit to the point of sale, this tag allows the automatic updating of the entity of stocks for each individual reference and its relevant movement, thus reducing administrative errors. By also allowing simultaneous registration of the tags of all the products placed within a shopping trolley, RFID becomes a source of benefit for the consumer and the firm, thanks to the consistent quantity of information obtainable even beyond the cash point barrier. 